\title{
The effect of cell disruption on the extraction of oil and protein from concentrated microalgae slurries
}

\author{
Ronald Halim $^{\mathrm{a}, \mathrm{b}, \mathrm{c}+}$, Ioannis Papachristou ${ }^{\mathrm{a}}$, George Q. Chen ${ }^{\mathrm{d}}$, Huining Deng, ${ }^{\mathrm{d}, \mathrm{e}}$, Wolfgang Frey ${ }^{\mathrm{a}}$, \\ Clemens Posten ${ }^{\mathrm{b}}$, Aude Silve ${ }^{\mathrm{a}}$
}

a Institute for Pulsed Power and Microwave Technology (IHM), Karlsruhe Institute of Technology (KIT), Eggenstein-Leopoldshafen, 76344, Germany

${ }^{\mathrm{b}}$ Institute of Process Engineering in Life Sciences, Bioprocess Engineering, Karlsruhe Institute of Technology (KIT), Karlsruhe, 76131, Germany

${ }^{c}$ School of Biosystems and Food Engineering, University College Dublin, Belfield, Dublin 4, Ireland

${ }^{\mathrm{d}}$ Department of Chemical Engineering, The University of Melbourne, Victoria, 3010, Australia

${ }^{\mathrm{e}}$ School of Chemical Engineering and Technology, Hebei University of Technology, Tianjin, 300130, PR China

+ corresponding author, email: ronald.halim@ucd.ie

Keywords: microalgae, wet biomass, pre-treatment, cell disruption, lipid extraction, protein extraction Nannochloropsis

\section{Highlights}

- Pre-treatments enhanced cell disruption in Nannochloropsis slurries

- Neutral lipid yield was directly dependent on the degree of cell disruption.

- Mechanical disruption was more effective for neutral lipid recovery.

- Protein yield was determined by both cell disruption and linkage hydrolysis.

- Chemical disruption was able to extract both structural and soluble proteins.

\begin{abstract}
Cell disruption is a critical step in the recovery of intracellular products from microalgae. In this study, novel biomass pre-treatments (autolytic incubation, hypotonic osmotic shock) were systematically combined with standard mechanical (high-pressure homogenisation) or chemical ( $\mathrm{pH}$ 12) disruption steps to investigate the fundamental mass transfer behaviours associated with the recoveries of intracellular lipids and proteins from lipid-rich Nannochloropsis slurries (biomass content $=140 \mathrm{mg}$ biomass / g slurry, total lipid content $=600 \mathrm{mg}$ lipid /g biomass).

Since neutral lipids exist as non-structural globules in the cytosols, their mass transfer was directly dependent on cell-wall disintegration. Neutral lipid yield was found to increase linearly with the degree of cell rupture regardless of the mechanical or chemical nature of the applied cell disruption process, reaching almost complete recovery (up to $90 \%$ of biomass neutral lipid) with complete cell disruption
\end{abstract}


(100\% disruption). Since HPH combinations were more effective in disintegrating cellular structures than $\mathrm{pH} 12$ combinations, they generally led to higher neutral lipid yields and were preferred for neutral lipid extraction.

On the other hand, proteins exist as both water-soluble fractions in the cytosols and structural fractions in the cell-walls and have a more complex extraction behaviour than neutral lipids. The mass transfer of the cytosolic proteins was found to be dependent on cell-wall disintegration, while that of the structural proteins was governed by both cell-wall disintegration and severance of protein linkage from the cell walls. HPH combinations lacked the capacity to cleave structural proteins from the cell-walls and were only able to release soluble proteins (up to $30 \%$ of total protein for our biomass). HPH disruption thus performed poorly in protein extraction despite having a high disruption efficiency. $\mathrm{pH} 12$ combinations had a robust rupture mechanism through the hydrolysis of chemical linkages in the cellwalls. This facilitated the release of both soluble and structural protein fractions and led to a more prolific protein yield (up to $80 \%$ of total biomass protein) compared to HPH combinations. pH12 disruption was therefore preferred for protein extraction.

\section{Introduction}

The establishment of a commercially viable microalgal bioindustry is paramount to the global pursuit of circular and sustainable bioeconomy and climate-change mitigation. The high costs associated with large-scale biomass processing, in particular that of biomass dehydration and cell disruption for the release of intracellular products, however, has continued to hamper the commercialisation of microalgae bioindustry (Halim, 2020; Halim et al., 2013; Vanthoor-Koopmans et al., 2013). Microalgal metabolites are intracellular in nature and can generally only be made accessible after liberation from cell-wall encapsulation.(Halim et al., 2019b; Halim et al., 2020). Microalgal cell walls are comprised of multilayered biopolymers that confer the cells with formidable defence against external processing (Baudelet et al., 2017; Canelli et al., 2021; Scholz et al., 2014).

The Nannochloropsis genus is industrially attractive because of its high basal level of valuable $\omega-3$ eicosapentaenoic acid (EPA) fatty acid (up to $12 \mathrm{wt} \%$ of biomass), ability to aggressively accumulate biofuel-precursor neutral lipids when subjected to nutrient depletion (total lipid content of up to $60 \mathrm{wt} \%$ of biomass) and proven metabolisms in assimilating waste nutrients during mixotrophic growth (Menegol et al., 2019; Olmstead et al., 2013; Poddar et al., 2018; Russo et al., 2021; Shene et al., 2016). Nannochloropsis cells are highly resistant to cell rupture, having previously been shown to possess a mechanically rigid and structurally complex cell wall that comprise of an outer algaenan layer and an inner layer made primarily of cellulose (Scholz et al., 2014). Finding an innovative means to rupture Nannochloropsis cell walls and render their intracellular components more accessible in their native wet state is critical in improving product recovery and resource efficiency of a microalgae biorefinery, while reducing the energy demand (and thus cost) of biomass processing. 
We have previously reported the use of autolytic incubation and hypotonic osmotic shocks as novel preparatory steps to weaken Nannochloropsis biomass in a concentrated slurry state (10 - $30 \mathrm{wt} \%$ biomass) and enhance product recoveries without drying (Halim et al., 2019a; Halim et al., 2019b; Halim et al., 2020; Halim et al., 2016). Even though they had different mechanisms, both pretreatments were shown to be highly effective in catalysing cell-wall/cell membrane degradation and rendering the Nannochloropsis biomass more susceptible to subsequent mechanical or chemical disruption steps. In the case of autolytic incubation (or thermally coupled dark anoxia incubation), the structural integrity of Nannochloropsis biomass was weakened via the activation of endogenous fermentation pathways which consumed structural sugars in the cell walls and thinned their overall thickness (by ca. 40\%) (Halim et al., 2019a; Halim et al., 2019b). Endogenous fermentation was induced by anaerobically incubating concentrated slurries in darkness at $35-38^{\circ} \mathrm{C}$ for an extended period $(16-24 \mathrm{~h})$ (Halim et al., 2019a; Halim et al., 2016). When subjected to subsequent disruptions (by HPH), the weakened postincubated slurries achieved ca $2 x$ the level cell disruption of the untreated slurries (Halim et al., 2019a). In the case of hypotonic osmotic shock, the structural integrity of the biomass was compromised via the delivery of a reverse osmotic gradient which resulted in the net diffusion of water into the cells, the build-up of internal pressure and the progressive damage to cell membrane (Halim et al., 2020). Reverse osmotic gradient was generated by freshwater washing (and reconstitution) of the slurry. When subjected to subsequent disruptions (by HPH), the washed slurries resulted in 2x the level of cell disruption of the untreated slurries (Halim et al., 2020). We have yet to directly compare the performance of autolytic incubation and hypotonic osmotic shock within the same study.

Despite the prolific number of studies investigating the release of bioproducts from microalgae biomass, most have investigated product yields from either dried biomass or dilute culture ( $<5 \mathrm{wt} \%$ biomass) rather than from concentrated slurries (Lee et al., 2010; Lee et al., 2017; Mubarak et al., 2015). Given the high energy cost and the risk of product degradation associated with biomass dehydration, it is critical that we focus our attention on product recovery from concentrated slurries (Dong et al., 2016; Laurens et al., 2015). Even though it has generally been understood that product yields increased with cell disruption, direct correlations between the degree of cell rupture and product extraction kinetics have rarely been reported (Halim et al., 2016; Safi et al., 2020; Yap et al., 2014). To the best of our knowledge, no study has yet to investigate the fundamental discrepancies in the mass transfer behaviour of different intracellular products from disrupted concentrated slurries. Products that are incorporated into the organellar and cell-wall structures (such as proteins) can be expected to exercise different mass transfer behaviours compared to non-structural products (such as neutral lipids).

Biofuel-convertible neutral lipids (or triglycerides) are accumulated in Nannochloropsis cells as cytosolic storage globules under nutrient deprivation (Bongiovani et al., 2020; Hulatt et al., 2017; Jia et al., 2015; Law et al., 2018; Simionato et al., 2011; Yap et al., 2016). Given their non-structural nature, the mass transfer of neutral lipids from the biomass to a non-polar extracting solvent is anticipated to depend on their accessibility which in turn is directly dependent on the degree of their liberation from 
the cell-wall encapsulation and the extent of cell rupture. On the other hand, proteins in the cells exist as both integral (or structural) components of the cell walls and cell membranes (e.g. glycoproteins) as well as in non-structural cytosolic forms (e.g. nucleic acids) (Phusunti \& Cheirsilp, 2020; Safi et al., 2017; Safi et al., 2013; Safi et al., 2014; Scherer et al., 2019; Soto-Sierra et al., 2018). Unlike lipids which require organic solvents, proteins can be directly extracted by the aqueous supernatants in the slurry upon being 'freed' from the biomass. Their dual structural/non-structural nature, however, implies that proteins will likely have a complicated mass transfer behaviour where cell rupture alone will not be sufficient to render them accessible. Additional chemical reactions which severe protein linkages with cell structures may be needed to liberate them the biomass.

Our study had dual objectives. The first objective was to investigate the effect of novel biomass pretreatments previously reported as being able to compromise microalgae structural integrity on the performance of standard mechanical and chemical treatments. To achieve this objective, we systematically subjected concentrated slurries of thickly walled Nannochloropsis biomass $(140 \mathrm{mg}$ biomass / g slurry) to different combinations of biomass pre-treatment (e.g. autolytic incubation, hypotonic osmotic shock, or both) with mechanical (high-pressure homogenisation) or chemical ( $\mathrm{pH}$ 12) disruption steps and evaluated the performance of the resulting biorefinery system in terms disruption efficiency, neutral lipid yield and protein yield. The second objective of the study was to investigate the relationships between the recoveries of cytosolic products (e.g. neutral lipids) and structural products (e.g. proteins) from concentrated microalgae slurries on the degree of cell disruption. To achieve this, we correlated the values of cell disruption obtained from our investigation on Nannochloropsis slurries with their respective neutral lipids yields and protein yields across all combinations. Through these correlations, we were able to elucidate the underpinning mass transfer mechanisms that drives the recovery of intracellular products from microalgae slurries and distil the discrepancies in the extraction behaviours of cytosolic and structural products. This study is the first to simultaneously investigate the dependence of neutral lipid recovery and protein recovery from concentrated microalgae slurries on the disruption of cell walls.

\section{Materials and Methods}

\subsection{Strain, cultivation and harvest}

N.gaditana strain (SAG 2.99) was acquired from the Culture Collection Centre at Georg-AugustUniversität Göttingen (SAG, Germany). After inoculation into a modified 3f medium on synthetic seawater in a bubble-column photobioreactor with $25 \mathrm{~L}$ working volume, the culture was cultivated with permanent white illumination (daily step increase from 120 to $370 \mu \mathrm{mol} \mathrm{m} \mathrm{m}^{-2} \mathrm{~s}^{-1}$ ) and continuous $\mathrm{CO}_{2}$-enriched aeration (air flow rate of $0.15 \mathrm{vvm}$ and a $\mathrm{CO}_{2}$-to-air ratio of 1/100 v/v) for 18 days as previously described (Halim et al., 2020). Nitrogen in the medium was depleted on day 10 of cultivation. There was a total of 7 cultivation cycles for biological replicates. At the end of each cultivation cycle, the culture was harvested from the PBR and centrifuged to form a slurry with a biomass concentration 
of $139.6 \pm 12.6 \mathrm{mg}$ biomass / g slurry. Approximately $480 \mathrm{~g}$ of slurry was generated from each harvest cycle. This was sufficient to supply all of the biomass needed for the experiments in section 2.2.

\subsection{Biomass pre-treatment, cell disruption, lipid extraction, protein extraction}

The slurry from each harvest (referred to as harvested slurries) was subjected to a series of pretreatment, cell disruption and lipid/protein extraction steps as shown in Figure 1. The slurry was divided into four separate batches, each undergoing a different pre-treatment step to weaken cell-wall integrity: no pre-treatment, autolytic incubation, osmotic shock and a dual pre-treatment of osmotic shock followed by autolytic incubation. Details of the pre-treatment steps are presented in section 2.2.1 2.2.3. The pre-treated slurries were further divided into three batches, each subjected to no disruption, mechanical disruption (with high-pressure homogenisation), or chemical disruption with base ( $\sim \mathrm{pH} 12$ ). Details of the cell-disruption steps are given in section 2.2.4 - 2.2.5.

Table 1 shows the complete matrix of experiments carried out in the study. Overall, there are 12 different combinations of pre-treatment + cell disruption. The disrupted slurries were then subjected to either lipid extraction (with hexane) or protein extraction. Details of the lipid extraction and protein extraction steps are provided in section 2.2.6 and 2.2.7 respectively. For every harvest, microalgal slurry was harvested and immediately subjected to the combination of pre-treatment and disruption steps outlined in Table 1 immediately on the same day that it was harvested. Approximately $5 \mathrm{~mL}$ of each slurry (i.e. harvested slurries, pre-treated slurries and disrupted slurries) was collected between each step and stored at $-20^{\circ} \mathrm{C}$ for analytical characterisation in section 2.3 .

\subsection{Autolytic incubation pre-treatment}

Autolytic incubation was carried out by incubating the harvested slurry in darkness at $38^{\circ} \mathrm{C}$ for $16 \mathrm{~h}$ using a method modified from our previous studies (Halim et al., 2019a; Halim et al., 2019b). The slurry ( 100 g) was placed in $2 \times 50 \mathrm{ml}$ vials leaving a small headspace for gas generation, covered in foil and stored in the oven at the required conditions.

\subsection{Osmotic shock pre-treatment}

Harvested slurry was subjected to hypotonic osmotic shock through two cycles of centrifugation and freshwater washing as previously described (Halim et al., 2020). In brief, $270 \mathrm{~g}$ of slurry was centrifuged $\left(7500 \mathrm{~g}, 20^{\circ} \mathrm{C}, 10 \mathrm{~min}\right)$, supernatant decanted and weighed before DI water at a mass equal to the collected supernatant ( $143 \mathrm{~g})$ was added to the microalgal pellet in order to reconstitute the slurry. The mixture was agitated, first with a spatula and then moderately with magnetic stirring for 30 min, to ensure complete homogeneity and the delivery of osmotic shock. Once the slurry was reconstituted, the hypotonic osmotic cycle was repeated a second time through another series of centrifugation, supernatant decanting, DI water addition and mixing.

\subsection{Osmotic shock + autolytic incubation dual pre-treatment}

Harvested slurry was subjected both osmotic shock and autolytic incubation. The slurry first underwent osmotic shock pre-treatment as described in section 2.2.2 before being incubated according to the autolytic incubation pre-treatment outlined in section 2.2.1. 


\subsection{Mechanical cell disruption with $\mathrm{HPH}$}

Pre-treated slurry ( $40 \mathrm{~g}$ ) was passed once through a high-pressure homogenisation (HPH) unit (Avestin EmulsiFlex-C3, Avestin, Canada) at 1000 - 1500 bar without any further dilution.

\subsection{Chemical cell disruption with base (pH 12)}

Aqueous sodium hydroxide solution (1M) was added dropwise to $25 \mathrm{~g}$ of pre-treated slurry to increase its $\mathrm{pH}$ value from $6.0 \pm 0.3$ to $12.3 \pm 0.2$. A total of $3-9 \mathrm{~g}$ of $\mathrm{NaOH}$ solution was added depending on the pre-treatment that the slurry had previously been subjected to. The mixture was moderately agitated before being incubated at $65^{\circ} \mathrm{C}$ for $2 \mathrm{~h}$.

\subsection{Neutral lipid extraction}

Lipid was extracted from disrupted slurry using two stages of biphasic hexane extraction. Disrupted slurry ( $4 \mathrm{~g}$ ) was mixed with an equal mass of hexane, tumbled using a rotation wheel at room temperature $\left(20^{\circ} \mathrm{C}\right)$ for $2 \mathrm{~h}$ and centrifuged to form four layers $\left(7000 \mathrm{~g}, 20^{\circ} \mathrm{C}, 10 \mathrm{~min}\right)$. After carefully isolating the top hexane layer with a glass pipette, the remaining post-centrifugation layers were mixed using a spatula and the resulting mixture was further subjected to another hexane extraction stage. Hexane phases recovered from both extraction stages were pooled and dried under $\mathrm{N}_{2}$ gas to enable gravimetric determination. The dried lipid extract was weighed before being re-dissolved in chloroform/methanol solution $(2: 1 \mathrm{v} / \mathrm{v})$ and stored at $-20^{\circ} \mathrm{C}$ until further analysis.

\subsection{Protein extraction}

Protein was extracted from disrupted slurry by centrifugation $\left(30000 \mathrm{~g}, 20^{\circ} \mathrm{C}, 10 \mathrm{~min}\right)$ and careful isolation of the resulting supernatant with a glass pipette. The supernatant was weighed and filtered $(0.22 \mu \mathrm{m})$ to remove any residual biomass. After appropriate dilution with DI water to ensure that protein concentration falls within the linear range of the Lowry method, the supernatant was subjected to a modified Lowry analysis in accordance with the supplier's instructions. Protein concentration was measured against a bovine serum albumin (BSA) calibration curve and corrected for dilution factor.

\subsection{Analytical characterisation}

\subsection{Biomass concentration and salt concentration of microalgal slurry}

The biomass concentration of microalgal slurries (140 mg biomass / $\mathrm{g}$ slurry) was determined gravimetrically by oven drying a known amount of slurry at $60^{\circ} \mathrm{C}$ for $16 \mathrm{~h}$.

\subsection{Total lipid content of microalgal biomass}

The total lipid content of microalgal biomass (harvested slurries and pre-treated slurries) was determined using a multiple-stage monophasic Bligh and Dyer extraction method as previously described (Halim et al., 2019b; Olmstead et al., 2013). Complete lipid recovery was verified through total bleaching of the cell debris after the final stage. The chloroform phases isolated from all extraction stages were pooled together, filtered $\left(0.2 \mu\right.$ mylon syringe filter) and dried under $\mathrm{N}_{2}$ gas for gravimetric measurement. The dried lipid was then re-dissolved in chloroform/methanol solution $(2: 1 \mathrm{v} / \mathrm{v})$ for lipid fractionation and/or fatty acid methyl ester analysis.

\subsection{Total protein content of microalgal biomass}


The total protein content of microalgal biomass (harvested slurries and pre-treated slurries) was determined through high-temperature alkaline hydrolysis of the slurry to release all intracellular proteins and subsequent analysis of the isolated serum with a Lowry assay. Microalgal slurry $(130 \mathrm{mg})$ was added to $2 \mathrm{ml}$ of $1 \mathrm{~N} \mathrm{NaOH}$ solution, heated at $95^{\circ} \mathrm{C}$ for $1 \mathrm{~h}$, cooled, and diluted appropriately with DI water to ensure that protein concentration falls within the linear range of the Lowry method. After centrifugation, the protein-rich serum was subjected to a modified Lowry analysis according to the supplier's instructions and the protein concentration was measured against a BSA calibration curve and corrected for dilution factor.

\subsection{Total sugar content of microalgal biomass}

The total sugar content of microalgal biomass (harvested slurries or pre-treated slurries) was determined using an anthrone-sulphuric acid assay. Microalgal slurry was diluted in DI water to a biomass concentration ranging between 0.1 and $0.4 \mathrm{~g}$ biomass /L. Freshly prepared starch standard solutions (Merck 1.01257, Merck, USA) in DI water were processed at the same time with microalgal slurries to generate a calibration curve. An aliquot of the diluted slurry or standard solution (400 $\mu \mathrm{l})$ was mixed with $800 \mu \mathrm{l}$ of freshly prepared anthrone reagent $(0.1 \% \mathrm{w} / \mathrm{v}$ in $95 \%$ sulphuric acid) prior to being heated at $95^{\circ} \mathrm{C}$ and $300 \mathrm{rpm}$ for $16 \mathrm{~min}$ and transferred to ice for cooling. Absorbance of the solution was measured at $625 \mathrm{~nm}$ and the carbohydrate was calculated using the standard curve generated during the analysis and corrected for the appropriate dilution factor.

\subsection{Lipid fractionation}

Lipid solutions (e.g. lipid extracts from hexane extraction in section 2.2.6 or total lipid extracts from Bligh \& Dyer extraction in section 2.3.2) were separated into constituent fractions by sequential elution with different solvent systems (chloroform for neutral lipids, acetone/methanol 9:1 v/v for glycolipids and methanol for phospholipids) in a SampliQ pre-packed silica cartridge (Agilent Technologies, USA) as previously described (Halim et al., 2019b; Olmstead et al., 2013).

\subsection{Fatty Acid Methyl Ester (FAME) analysis}

Lipid solutions (e.g. lipid extracts from hexane extraction in section 2.2.6 or total lipid extracts from Bligh \& Dyer extraction in section 2.3.2) were subjected to lipid transesterification and FAME analysis as previously described (Halim et al., 2019a). Chromatographic separation was carried out using an Agilent 7890B Gas Chromatography unit with a Flame Ionisation Detector (Agilent Technologies, USA) and a capillary column. A known amount of C15:0 FAME internal standard was spiked to each solution to enable quantification (Sigma Aldrich, USA). Individual FAMEs were identified by retention-time comparison with a mixed FAME 18917 Supelco standard (Sigma Aldrich, USA).

\subsection{Cell disruption evaluation}

The disruption efficiency of the pre-treatment (section 2.2.1 - 2.2.3) and cell disruption (section 2.2.4 - 2.2.5) steps was evaluated via automated cell count of the captured microscopic images. Harvested, pre-treated or disrupted slurry was diluted to an appropriate concentration for microscopic imaging (mass dilution ratio ca 540 and 630x) and placed on a standard Neubauer haemocytometer (10 $\mu$ ) for 
15 min before being observed under a Zeiss Axioplan 2 light microscope (roughly 12 images of different $0.04 \mathrm{~mm}^{2}$ haemocytometer grids were captured). The apparent number of intact cells in each captured image was evaluated using an automated ImageJ algorithm as previously described and corrected for dilution factor (Halim et al., 2019a). The extent of cell rupture (\% of cells) for a specific slurry (e.g. pre-treated or disrupted slurry) measured the level of physical destruction of the cells and was calculated as follows:

The extent of cell rupture $=\frac{\overline{\mathrm{C}}_{\text {harvested slurry }}-\overline{\mathrm{C}}_{\text {specific slurry }}}{\overline{\mathrm{C}}_{\text {harvested slurry }}} \cdot 100$

where $\overline{\mathrm{C}}_{\text {harvested slurry }}$ was the average apparent number of intact cells for the harvested slurry (cells/g

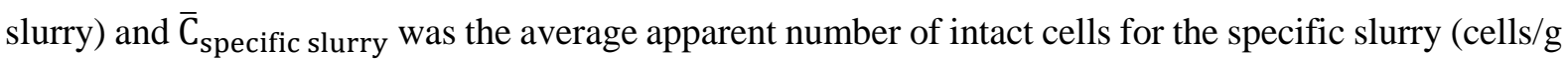
slurry).

\section{Results and Discussion}

\subsection{Biomass composition}

The harvested Nannochloropsis biomass is rich in lipid, having a total lipid content of $607.0 \pm 102.5$ $\mathrm{mg} / \mathrm{g}$ biomass (total fatty acid content $=449.0 \mathrm{mg} / \mathrm{g}$ biomass), total sugar content $249.9 \pm 40.1 \mathrm{mg} / \mathrm{g}$ biomass, and total protein content $143.1 \pm 34.6 \mathrm{mg} / \mathrm{g}$ biomass.

The biomass appears to have a suitable lipid fractions and fatty acid composition for biofuel conversion, with neutral lipid fraction constituting the majority of the total lipid extract (neutral lipid content $=76.0$ $\pm 16.1 \mathrm{wt} \%$ of total lipid or $461.4 \pm 97.6 \mathrm{mg} / \mathrm{g}$ biomass) and saturated (SFA) and monounsaturated (MUFA) fatty acids dominating the fatty acid profile of the total lipid (Table 2, total SFA and MUFA contents $=91.7 \mathrm{wt} \%$ of fatty acids or $411.8 \mathrm{mg} / \mathrm{g}$ biomass). Neutral lipid is the preferred fraction for biofuel application given the potential toxicity of polar lipid head groups to transesterification catalyst (Halim et al., 2012; Olmstead et al., 2013). High levels of SFAs and MUFAs are also desirable as they form biodiesel with better cold-flow properties and higher oxidative stability (Halim et al., 2012; Olmstead et al., 2013). The alignment between lipid fraction and fatty acid suitability for biofuel production was expected as $\mathrm{N}$-depleted Nannochloropsis biomass has previously been shown to accumulate neutral lipids (in the form of TAGs) constituting primarily of SFAs and MUFAs (Bongiovani et al., 2020; Jia et al., 2015; Olmstead et al., 2013; Simionato et al., 2013).

\subsection{Effect of pre-treatment on cell disruption}

Figure $2 \mathrm{a}$ and Table 1 showed that the pre-treatment steps generally had a positive effect on the extent of Nannochloropsis cell rupture by both mechanical and chemical cell disruptions steps. Without the pre-treatment steps, HPH disruption and $\mathrm{pH} 12$ disruption were relatively ineffective in disrupting cellular structure, being able to only rupture a mere 28 and $13 \%$ of available cells. These findings further underscored the toughness of lipid-rich Nannochloropsis cell walls and the need for a preparatory or pre-treatment step able to weaken cell wall integrity and enhance the performance of subsequent cell disruption for maximum product liberation. Theoretically, the disruption performance of either HPH and $\mathrm{pH} 12$ can be increased by subjecting the slurries to more severe process conditions (e.g. higher 
pressure and more passes for HPH or higher temperature and higher $\mathrm{pH}$ for alkali treatment), but this also increases cost/energy requirements, degradation probabilities of thermolabile components and undesirable hydrolytic side reactions.

The autolytic incubation was able to enhance cell disruption of HPH and pH12 by 2.4 and 4.9 fold respectively. As described in our previous studies (Halim et al., 2019a; Halim et al., 2019b), the increase in disruption efficiency was derived from cell-wall thinning which weakened cellular integrity and rendered the biomass more susceptible to subsequent processing.

Hypotonic osmotic shock was also found to be able to enhance cell disruption, increasing the extent of cell rupture of $\mathrm{HPH}$ and $\mathrm{pH} 12$ by 1.6 fold and 1.4 fold respectively. Compared to autolytic incubation, however, the weakening effect of hypotonic osmotic shock was less pronounced. This could be attributed to the fact that osmotic shock weakened biomass by increasing membrane permeability rather than directly thinning cell walls (Halim et al., 2020).

For HPH, the combination of the two pre-treatment steps (autolytic incubation and hypotonic osmotic shock) produced a synergistic effect which disrupted close to $90 \%$ of available cells. Overall, these findings suggested the effectiveness of the pre-treatment steps in enhancing Nannochloropsis cell disruption when applied either as an individual step or in combination with each other.

In industrial settings, it is important to note that the inclusion of a pre-treatment step would lead to increased cost and energy requirements for biomass processing. These extra costs should be balanced against the benefits of implementing such pre-treatment steps in terms of product yields. In our previous study, we have shown that implementing the hypotonic osmotic shock in industrial scale (processing one tonne of slurry) accounted for less than $6 \%$ of the overall energy expenditure of biomass processing and led to a positive overall net energy balance of biomass processing for oleaginous microalgae with a neutral lipid content of more than $30 \mathrm{wt} \%$ biomass, such as the Nannochloropsis biomass used in this study (Halim et al., 2020). A comprehensive cost-benefit and energy assessment for the pre-treatment steps reported in this study, however, is beyond its scope. Instead, this study will use the microalgae biorefinery system to achieve multiple levels of cell disruption for thickly walled Nannochloropsis biomass for investigation into the fundamental behaviours of lipid and protein mass transfer.

\subsection{Partitioning behaviour of mechanical and chemical cell disruption}

In this section, we examined the partition behaviour of the different slurries generated by the mechanical (HPH) and chemical (pH12) biorefineries. As illustrated in Figure 1, the disrupted Nannochloropsis slurries (post HPH or pH12 treatment) were subjected to both neutral lipid extraction (with hexane) and protein extraction. Once the extraction mixture was centrifuged, the desired products can be recovered from the appropriate phases.

Figure 3 shows phase partitioning of the four representative key scenarios encountered in our experimental matrix: 1) HPH + neutral lipid extraction with hexane (exp 11), 2) pH12 + neutral lipid extraction with hexane (exp 12), 3) $\mathrm{HPH}+$ protein extraction (exp 11), and 4) $\mathrm{pH} 12$ + protein extraction 
(exp 12). We note that there were no discernible differences in the partitioning behaviour of biorefineries obtained from differently pretreated biomass, i.e. untreated slurries (exp 2), autolytically incubated slurries (exp 5), osmotically shocked slurries (exp 8) and both autolytically incubated and osmotically shocked slurries (exp 11) all shared the same partitioning behaviour once subjected to HPH and neutral lipid extraction with hexane. As discussed below, however, since pretreated slurries are likely to experience more prolific cell disruption and product liberation, they produced darker layers with higher levels of dissolved products.

For HPH + neutral lipid extraction, the slurries partitioned into four distinct layers (Figure 3a): 1) a top hexane layer containing the extracted lipids (which included neutral lipids and non-polar pigments, such as chlorophyll), 2) an emulsion layer comprised of a mixture of cell debris/intact cells, water and residual hexane, 3) an aqueous layer containing salts, and 4) a bottom cell debris layer containing water and cell debris. Readers are referred to our previous study for detailed understanding of the HPH + hexane extraction layers (Halim et al., 2016). Neutral lipids were gravimetrically quantified from the hexane phase.

For $\mathrm{pH} 12$ + neutral lipid extraction, the slurries partitioned into five layers (Figure 3b): 1) a top hexane layer containing the extracted lipids, 2) a saponification layer where part of the extracted lipids appeared to have reacted with $\mathrm{NaOH}$ to form a gel-like soap layer, 3) an emulsion layer comprised of a mixture of cell debris/intact cells, water and residual hexane, 4) an aqueous layer containing salts and watersoluble pigment breakdown products, and 5) a bottom cell debris layer containing water and cell debris. The primary difference between HPH-lipid extraction layers with pH12-lipid extraction layers lies on the location of the recovered pigments. Unlike HPH layers where the extracted pigments remained water insoluble and thus partitioned in the hexane phase together with extracted neutral lipids (thus contributing to the dark coloration of the lipid layer), the pigments in the $\mathrm{pH} 12$ biorefinery have reacted with $\mathrm{NaOH}$ to form water-soluble chlorophyllin which partitioned in the aqueous phase, contributing to the dark coloration of the aqueous layer and a lighter hexane phase (Li et al., 2016). The use of $\mathrm{NaOH}$ as a bleaching agent to remove chlorophyll from microalgae biomass/oil has previously been reported (Li et al., 2016). Extracted neutral lipids were gravimetrically quantified from the hexane phase.

Both $\mathrm{HPH}+$ protein extraction slurries (Figure 3c) and $\mathrm{pH} 12$ + protein extraction slurries (Figure 3d) separated into three layers: a top emulsion layer comprised of cell debris in water, a middle supernatant aqueous layer (or mid-natant layer) consisting of the released proteins, a bottom cell debris layer containing intact cells, cell debris and dissolved salts in water. The extracted protein was quantified from the middle supernatant layer using a Lowry method.

\subsection{Relationship between cell disruption and neutral lipid recovery}

HPH combinations were generally found to be more effective in disintegrating cellular structures compared to $\mathrm{pH} 12$ combinations (Figure $2 \mathrm{~b}$ ). This was expected given the high level of shear force delivered by HPH disruption (Lee et al., 2017; Safi et al., 2017; Safi et al., 2014). Neutral lipid yield of subsequent hexane extraction step appeared to follow the same pattern as cell rupture, with HPH 
combinations obtaining a higher yield compared to $\mathrm{pH} 12$ combinations and being the preferred disruption options for lipid recovery. These findings suggested a positive connection between cell rupture and neutral lipid yield.

To further probe the relationship between the extent of cell rupture and neutral lipid recovery, we plotted neutral lipid yield as a function of cell rupture across all experiments which included either mechanical or chemical disruption (Figure 4a). The correlation revealed a linear relationship between the two variables $\left(r^{2}=0.91\right)$. Equally importantly, with a gradient close to $1(\mathrm{k}=0.89)$, the correlation established that almost all of the available neutral lipids in the biomass can be recovered (e.g. neutral lipid yield $=90 \mathrm{wt} \%$ of total neutral lipid in the biomass) if complete cell disruption had been achieved (e.g. extent of cell rupture $=100 \%$ of cells in the slurry).

The direct dependence of neutral lipid recovery on the extent of cell rupture can likely be attributed to the nature of neutral lipids as cytosolic globules that are 'trapped' within the cell walls but are not chemically linked to any cellular structures or organelles (Bongiovani et al., 2020; Law et al., 2018; Simionato et al., 2013; Yap et al., 2016; Yap et al., 2014). The mass transfer of neutral lipids from the biomass into the extracting solvent was hence almost entirely dependent on the extent of their liberation from cell-wall encapsulation. Once these barriers were physically destroyed, the 'freed' neutral lipid globules became accessible to the extracting solvent for solubilisation. An increase in the degree of cell disruption therefore led to an increase in the amount of liberated neutral lipids which subsequently increased their mass transfer to the extracting solvent.

An interesting element of the relationship between cell disruption and neutral lipid recovery was its independence from disruption mode. The correlation depicted in Figure 4a spanned both mechanically and chemically disrupted biomass, producing a single equation for both disruption modes. The correlation appeared to be accurate regardless of whether cell-wall breakage was achieved via a mechanical means or a chemical means. Such independence from cell disruption mode was again likely ascribed to the non-structural nature of neutral lipids. As long as the disruption process was able break the cell walls and release the neutral lipid globules (without inflicting noticeable lipid degradation) for solvent solubilisation, the specific mechanism by which the wall breakage was achieved (e.g. shear by HPH or linkage hydrolysis by $\mathrm{pH} 12$ ) did not seem to contribute to the resulting neutral lipid mass transfer from the biomass into the solvent phase. Within the limits of our experiments, the HPH combinations generally achieved a higher cell disruption and thus a higher neutral lipid yield compared to $\mathrm{pH} 12$ combinations. For this reason, they occupied the upper half of the correlation in Figure 4a.

Figure 5 depicts our proposed mass-transfer mechanism for the extraction of neutral lipids from Nannochloropsis slurry using hexane. At partial cell disruption (i.e. the extent of cell rupture $<100 \%$ of cells in the slurry), a mixture of intact cells and disrupted cells exists in the slurry. When subjected to extraction with hexane, liberated lipid globules from the disrupted cells can interact with the solvent and diffuse out of the biomass, while those in the intact cells remain inaccessible to the solvent. Upon centrifugation, the solubilised lipids will partition in the hexane phase while those in the intact cells 
remain with the biomass. The lipid extraction efficiency is therefore proportional to the level of disrupted cells in the slurry. At complete cell disruption (i.e. the extent of cell rupture $=100 \%$ of cells in the slurry), all available cells in the slurry have been disrupted, leading to the release of all neutral lipid globules from cell-wall encapsulation. Hexane extraction of the slurry would therefore theoretically lead to complete solubilisation (and thus recovery of all neutral lipids from the biomass. In practice, however, a level of residual neutral lipids would likely remain in the biomass due to incomplete solvent separation (i.e. the formation of post-centrifugation emulsion layer in Figure $3 \mathrm{a}$ where some solvents containing dissolved lipids appeared to have partitioned together with the biomass in the aqueous phase). The proposed mass-transfer was valid across both mechanical (HPH) and chemical (pH12) disruption.

\subsection{Relationship between cell disruption and protein recovery}

The pattern for protein extraction yield in Figure $2 \mathrm{c}$ appeared to be in opposite direction to the extent of cell rupture. The apparent protein yields of $\mathrm{pH} 12$ combinations were higher than those reported by HPH combinations, despite the chemical treatment's lower disruption efficiency. These results contradicted our initial understanding of the effect of cell disruption and prompted us to further probe the relationship between the two variables by plotting protein yield as a function of cell disruption across all HPH experiments and all pH12 experiments (Figure 4b).

A plot of protein yield as a function of the extent of cell rupture generated two separate correlations, one for HPH combinations (or.mechanical treatment) and another for $\mathrm{pH} 12$ combinations (or chemical treatment). Unlike neutral lipid extraction, the behaviour of protein mass transfer was hence found to be dependent on the mode of cell disruption.

Both correlations established a positive relationship between protein yields and the extent of cell rupture, confirming that cell-wall disintegration led to a higher protein release from the biomass into the interstitial space. However, the extent to which this release occurred was vastly different between pH12 experiments and HPH experiments. With a much steeper gradient $(\mathrm{k}=0.96), \mathrm{pH} 12$ treatment was shown to be superior in facilitating protein release compared to HPH treatment $(\mathrm{k}=0.22)$. The discrepancy in extraction behaviours can be attributed to the complex nature of intracellular proteins and the. differing abilities of the two disruption modes in interacting with different proteins.

Intracellular proteins exist as both non-structural proteins dissolved/suspended in the cytosols and structural proteins that form an integral component of the cell wall/membrane through biochemical linkages. Both types of proteins are 'trapped' by the cell walls. However, unlike non-structural proteins that can be 'freed' or liberated from the biomass by mere physical destruction of the cell walls, structural proteins require additional reactions able to severe their connection with cellular structure to be released (Phusunti \& Cheirsilp, 2020; Safi et al., 2014; Scherer et al., 2019; Soto-Sierra et al., 2018). Without breaking the bonds that connect them to cell membranes/walls, structural proteins cannot be separated 
from the broken cell debris after cell disruption and simply partition in the biomass layer (instead of the aqueous layer, Figure $3 \mathrm{c}, \mathrm{d}$ ) after centrifugation.

HPH disintegrated the cell walls through brute shear force mediated by physical collisions. Even though these actions were able to 'free' cytosolic proteins from the biomass, they failed to cleave structural proteins from the biomass. Mechanical disruption was therefore able to efficiently release cytosolic proteins, yet it had a limited capacity in liberating structural proteins. A closer inspection of the HPH curve verified this hypothesis. The curve had a positive gradient (albeit at a low value), demonstrating increased release of cytosolic proteins with cell rupture. However, the HPH curve had an imposed upper limit in the total amount of recoverable proteins. Despite being very effective in disintegrating cellular structure (i.e. the extent of cell rupture reaching almost $100 \%$ of cells for some experiments), the most efficient HPH combinations were only able to recover a maximum protein yield of $30 \%$. This upper threshold in the level of extractable protein by HPH disruption represented the amount of cytosolic proteins available in the biomass. Structural proteins remained embedded in the cell debris after cell disruption.

Alkaline (pH12) treatment hydrolysed cell wall linkages and achieved cell disruption through slow solubilisation of cell-wall layers (Mendez et al., 2013; Safi et al., 2014; Wu et al., 2017). Chemical treatment is often carried out at extreme and highly degradative temperature range $\left(>100^{\circ} \mathrm{C}\right)$ to exert sufficient disruption of thickly walled microalgae species (e.g. Chlorella sp. and Nannochloropsis sp) in slurry form (Laurens et al., 2015). However, the inclusion of pretreatment steps in our experiments has considerably weakened the biomass to a point that we were able to observe significant disruption at milder conditions $\left(\mathrm{T}=65^{\circ} \mathrm{C}\right)$. Alkaline treatment had the capacity to achieve quantitative protein extraction as it was able to release both cytosolic proteins through cell wall disintegration and structural proteins through bond-cleaving reactions. A closer inspection of the $\mathrm{pH} 12$ curve in Figure $4 \mathrm{~b}$ confirmed this hypothesis. With a gradient close to one, the treatment can be projected to recover all available biomass proteins at $100 \%$ disruption efficiency (likely achievable by extending the duration of the alkali treatment or increasing $\mathrm{pH}$ ).

Figure 6 illustrates our proposed mass-transfer mechanisms for the extraction of proteins from Nannochloropsis slurry with either mechanical disruption or chemical disruption. For mechanical disruption, at partial cell disruption (i.e., the extent of cell rupture $<100 \%$ of cells in the slurry), a mixture of intact cells and disrupted cells exists in the slurry. Mechanical disruption's limited capacity in cleaving structural proteins means that only cytosolic proteins are released from the disrupted cells, while structural proteins in the cell fragments and all proteins in the intact cells remain inaccessible. Upon centrifugation, the water-soluble proteins will partition in the water phase while the structural proteins that remain attached to cell debris and proteins in the intact cells will partition in the cell-debris layer. At complete cell disruption (i.e. the extent of cell rupture $=100 \%$ of cells in the slurry), all available soluble proteins will be released (roughly $30 \%$ of all proteins in our biomass), while structural proteins will partition in the cell-debris layer and remain unextracted. 
For chemical disruption, while the intracellular proteins in the intact cells remain inaccessible, the dual disruption mechanism catalysed by chemical hydrolysis will facilitate the release of both cytosolic and structural proteins from the ruptured cells. At partial disruption, an increase in the degree of cell rupture leads to more prolific release of intracellular proteins, establishing a proportional relationship between protein yields and the degree of cell rupture. Once separated, all available proteins from the ruptured cells will partition in the water phase, while proteins in the intact cells will remain in the biomass and partition in the cell-debris phase. At complete cell disruption, chemical disruption is able to release all available intracellular proteins, leading to the complete recovery of proteins from the biomass.

\section{Conclusions}

In conclusions, our study investigated the effect of combining novel biomass pre-treatments (autolytic incubation able to induce cell-wall thinning, hypotonic osmotic shock able to render cell membrane to be more permeable) with HPH or $\mathrm{pH} 12$ disruption steps on system performance and the mass transfer of neutral lipids and proteins from resistant Nannochloropsis slurries. Both pre-treatments were shown to be highly effective in improving disruption efficiency of the system, with the autolytic incubation and osmotic shock being able to enhance the extent of cell rupture by 2.4-4.9 and 1.4-1.6 folds respectively.

Neutral lipids exist as non-structural cytosolic globules trapped within cell-wall encapsulation. Their release from the biomass was directly dependent on the degree of physical cell disruption. Since shearbased HPH disruption was found to be more effective in disintegrating cell walls compared to $\mathrm{pH} 12$ disruption, they also resulted in higher neutral lipid yields. The highest neutral lipid yield $(78 \pm 7 \mathrm{wt} \%$ of total neutral lipid) was achieved with osmotic shock +autolytic incubation +HPH combination.

On the other hand, intracellular proteins exist in both cytosolic and structural forms. Their release from the biomass was dependent on both the degree of physical cell disruption and the extent to which structural linkages in the biomass were severed. Since pH12 disruption achieved cell rupture through the solubilisation of cell-wall linkages, it was able to more effectively release proteins compared to $\mathrm{HPH}$ disruption. The highest protein yield ( $66 \pm 9 \mathrm{wt} \%$ of total protein) was achieved with osmotic shock +autolytic incubation $+\mathrm{pH} 12$ combination.

\section{Acknowledgements}

$\mathrm{RH}$ is grateful for the generous supports received from the Alexander von Humboldt Postdoctoral Research Fellowship 2017 - 2018 (Ref 3.1-AUS-1192825-HFST-P). The authors would also like to thank the Helmholtz Research Program on Renewable Energies [Topic 3: Bioenergy] and EU's Horizon 2020 Research and Innovation program [Grant Agreement No. 727874] for their financial support. 


\section{References}

Baudelet, P.-H., Ricochon, G., Linder, M., Muniglia, L. 2017. A new insight into cell walls of Chlorophyta. Algal Research, 25, 333-371.

Bongiovani, N., Popovich, C.A., Martínez, A.M., Constenla, D., Leonardi, P.I. 2020. Biorefinery Approach from Nannochloropsis oceanica CCALA 978: Neutral Lipid and Carotenoid CoProduction Under Nitrate or Phosphate Deprivation. BioEnergy Research, 13(2), 518-529.

Canelli, G., Murciano Martínez, P., Austin, S., Ambühl, M.E., Dionisi, F., Bolten, C.J., Carpine, R., Neutsch, L., Mathys, A. 2021. Biochemical and Morphological Characterization of Heterotrophic Crypthecodinium cohnii and Chlorella vulgaris Cell Walls. Journal of Agricultural and Food Chemistry, 69(7), 2226-2235.

Dong, T., Knoshaug, E.P., Pienkos, P.T., Laurens, L.M.L. 2016. Lipid recovery from wet oleaginous microbial biomass for biofuel production: A critical review. Applied Energy, 177, 879-895.

Halim, R. 2020. Industrial Extraction of Microalgal Pigments. Springer, Cham.

Halim, R., Danquah, M.K., Webley, P.A. 2012. Extraction of oil from microalgae for biodiesel production: A review. Biotechnology Advances, 30(3), 709-732.

Halim, R., Harun, R., Webley, P.A., Danquah, M.K. 2013. Bioprocess Engineering Aspects of Biodiesel and Bioethanol Production from Microalgae. in: Advanced Biofuels and Bioproducts, (Ed.) J.W. Lee, Springer New York. New York, NY, pp. 601-628.

Halim, R., Hill, D.R.A., Hanssen, E., Webley, P.A., Blackburn, S., Grossman, A.R., Posten, C., Martin, G.J.O. 2019a. Towards sustainable microalgal biomass processing: anaerobic induction of autolytic cell-wall self-ingestion in lipid-rich Nannochloropsis slurries. Green Chemistry.

Halim, R., Hill, D.R.A., Hanssen, E., Webley, P.A., Martin, G.J.O. 2019b. Thermally coupled darkanoxia incubation: A platform technology to induce auto-fermentation and thus cell-wall thinning in both nitrogen-replete and nitrogen-deplete Nannochloropsis slurries. Bioresource Technology, 290, 121769.

Halim, R., Papachristou, I., Kubisch, C., Nazarova, N., Wüstner, R., Steinbach, D., Chen, G.Q., Deng, H., Frey, W., Posten, C., Silve, A. 2020. Hypotonic osmotic shock treatment to enhance lipid and protein recoveries from concentrated saltwater Nannochloropsis slurries Fuel, Accepted on 06/10/2020.

Halim, R., Webley, P.A., Martin, G.J.O. 2016. The CIDES process: Fractionation of concentrated microalgal paste for co-production of biofuel, nutraceuticals, and high-grade protein feed. Algal Research, 19, 299-306.

Hulatt, C.J., Wijffels, R.H., Bolla, S., Kiron, V. 2017. Production of Fatty Acids and Protein by Nannochloropsis in Flat-Plate Photobioreactors. PLOS ONE, 12(1), 1-17.

Jia, J., Han, D., Gerken, H.G., Li, Y., Sommerfeld, M., Hu, Q., Xu, J. 2015. Molecular mechanisms for photosynthetic carbon partitioning into storage neutral lipids in Nannochloropsis oceanica under nitrogen-depletion conditions. Algal Research, 7, 66-77.

Laurens, L.M.L., Nagle, N., Davis, R., Sweeney, N., Van Wychen, S., Lowell, A., Pienkos, P.T. 2015. Acid-catalyzed algal biomass pretreatment for integrated lipid and carbohydrate-based biofuels production. Green Chemistry, 17(2), 1145-1158.

Law, S.Q.K., Halim, R., Scales, P.J., Martin, G.J.O. 2018. Conversion and recovery of saponifiable lipids from microalgae using a nonpolar solvent via lipase-assisted extraction. Bioresource Technology, 260, 338-347.

Lee, J.-Y., Yoo, C., Jun, S.-Y., Ahn, C.-Y., Oh, H.-M. 2010. Comparison of several methods for effective lipid extraction from microalgae. Bioresource Technology, 101(1, Supplement), S75-S77.

Lee, S.Y., Cho, J.M., Chang, Y.K., Oh, Y.-K. 2017. Cell disruption and lipid extraction for microalgal biorefineries: A review. Bioresource Technology, 244, 1317-1328.

Li, T., Xu, J., Wu, H., Wang, G., Dai, S., Fan, J., He, H., Xiang, W. 2016. A Saponification Method for Chlorophyll Removal from Microalgae Biomass as Oil Feedstock. Marine drugs, 14(9), 162. 
Mendez, L., Mahdy, A., Timmers, R.A., Ballesteros, M., González-Fernández, C. 2013. Enhancing methane production of Chlorella vulgaris via thermochemical pretreatments. Bioresource Technology, 149, 136-141.

Menegol, T., Romero-Villegas, G.I., López-Rodríguez, M., Navarro-López, E., López-Rosales, L., Chisti, Y., Cerón-García, M.C., Molina-Grima, E. 2019. Mixotrophic production of polyunsaturated fatty acids and carotenoids by the microalga Nannochloropsis gaditana. Journal of Applied Phycology, 31(5), 2823-2832.

Mubarak, M., Shaija, A., Suchithra, T.V. 2015. A review on the extraction of lipid from microalgae for biodiesel production. Algal Research, 7, 117-123.

Olmstead, I.L.D., Hill, D.R.A., Dias, D.A., Jayasinghe, N.S., Callahan, D.L., Kentish, S.E., Scales, P.J., Martin, G.J.O. 2013. A quantitative analysis of microalgal lipids for optimization of biodiesel and omega-3 production. Biotechnology and Bioengineering, 110(8), 2096-2104.

Phusunti, N., Cheirsilp, B. 2020. Integrated protein extraction with bio-oil production for microalgal biorefinery. Algal Research, 48, 101918.

Poddar, N., Sen, R., Martin, G.J.O. 2018. Glycerol and nitrate utilisation by marine microalgae Nannochloropsis salina and Chlorella sp. and associated bacteria during mixotrophic and heterotrophic growth. Algal Research, 33, 298-309.

Russo, G.L., Langellotti, A.L., Oliviero, M., Sacchi, R., Masi, P. 2021. Sustainable production of food grade omega-3 oil using aquatic protists: Reliability and future horizons. New Biotechnology, 62, 32-39.

Safi, C., Cabas Rodriguez, L., Mulder, W.J., Engelen-Smit, N., Spekking, W., van den Broek, L.A.M., Olivieri, G., Sijtsma, L. 2017. Energy consumption and water-soluble protein release by cell wall disruption of Nannochloropsis gaditana. Bioresource Technology, 239, 204-210.

Safi, C., Charton, M., Pignolet, O., Silvestre, F., Vaca-Garcia, C., Pontalier, P.-Y. 2013. Influence of microalgae cell wall characteristics on protein extractability and determination of nitrogento-protein conversion factors. Journal of Applied Phycology, 25(2), 523-529.

Safi, C., Charton, M., Ursu, A.V., Laroche, C., Zebib, B., Pontalier, P.-Y., Vaca-Garcia, C. 2014. Release of hydro-soluble microalgal proteins using mechanical and chemical treatments. Algal Research, 3, 55-60.

Safi, C., Olivieri, G., Engelen-Smit, N., Spekking, W., Veloo, R., den Broek, L.A.M.v., Sijtsma, L. 2020. Effect of growth conditions on the efficiency of cell disruption of Neochloris oleoabundans. Bioresource Technology, 300, 122699.

Scherer, D., Krust, D., Frey, W., Mueller, G., Nick, P., Gusbeth, C. 2019. Pulsed electric field (PEF)assisted protein recovery from Chlorella vulgaris is mediated by an enzymatic process after cell death. Algal Research, 41, 101536.

Scholz, M.J., Weiss, T.L., Jinkerson, R.E., Jing, J., Roth, R., Goodenough, U., Posewitz, M.C., Gerken, H.G. 2014. Ultrastructure and Composition of the Nannochloropsis gaditana Cell Wall. Eukaryotic Cell, 13(11), 1450-1464.

Shene, C., Chisti, Y., Vergara, D., Burgos-Díaz, C., Rubilar, M., Bustamante, M. 2016. Production of eicosapentaenoic acid by Nannochloropsis oculata: Effects of carbon dioxide and glycerol. Journal of Biotechnology, 239, 47-56.

Simionato, D., Block, M.A., La Rocca, N., Jouhet, J., Marechal, E., Finazzi, G., Morosinotto, T. 2013. The response of Nannochloropsis gaditana to nitrogen starvation includes de novo biosynthesis of triacylglycerols, a decrease of chloroplast galactolipids, and reorganization of the photosynthetic apparatus. Eukaryot Cell, 12(5), 665-76.

Simionato, D., Sforza, E., Corteggiani Carpinelli, E., Bertucco, A., Giacometti, G.M., Morosinotto, T. 2011. Acclimation of Nannochloropsis gaditana to different illumination regimes: Effects on lipids accumulation. Bioresource Technology, 102(10), 6026-6032.

Soto-Sierra, L., Stoykova, P., Nikolov, Z.L. 2018. Extraction and fractionation of microalgae-based protein products. Algal Research, 36, 175-192. 
Vanthoor-Koopmans, M., Wijffels, R.H., Barbosa, M.J., Eppink, M.H.M. 2013. Biorefinery of microalgae for food and fuel. Bioresource Technology, 135, 142-149.

Wu, C., Xiao, Y., Lin, W., Li, J., Zhang, S., Zhu, J., Rong, J. 2017. Aqueous enzymatic process for cell wall degradation and lipid extraction from Nannochloropsis sp. Bioresource Technology, 223, 312-316.

Yap, B.H.J., Crawford, S.A., Dagastine, R.R., Scales, P.J., Martin, G.J.O. 2016. Nitrogen deprivation of microalgae: effect on cell size, cell wall thickness, cell strength, and resistance to mechanical disruption. Journal of Industrial Microbiology \& Biotechnology, 43(12), 1671-1680.

Yap, B.H.J., Crawford, S.A., Dumsday, G.J., Scales, P.J., Martin, G.J.O. 2014. A mechanistic study of algal cell disruption and its effect on lipid recovery by solvent extraction. Algal Research, $\mathbf{5}$, 112-120. 


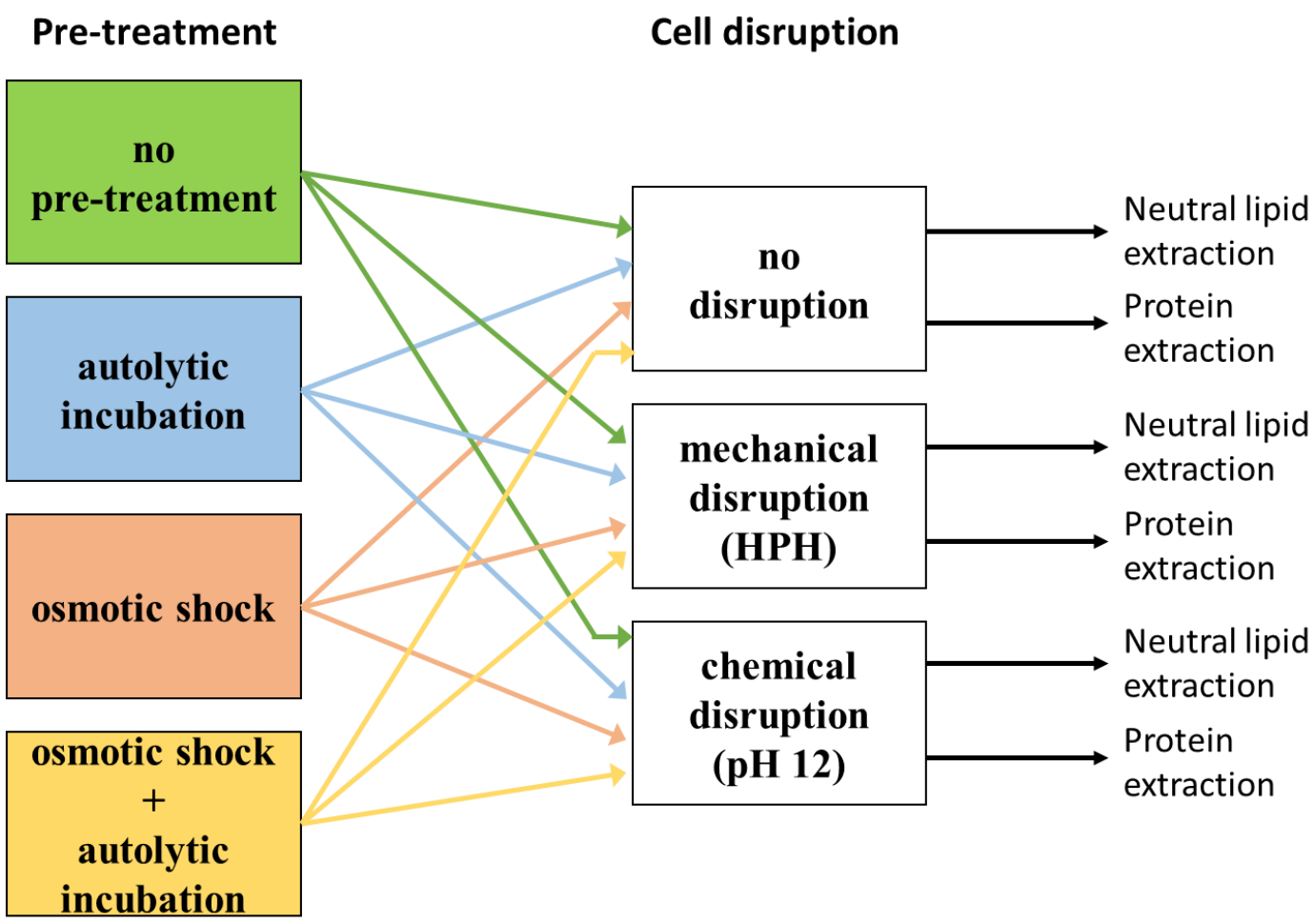

Figure 1. Flow Diagram of the Experimental Matrix. 


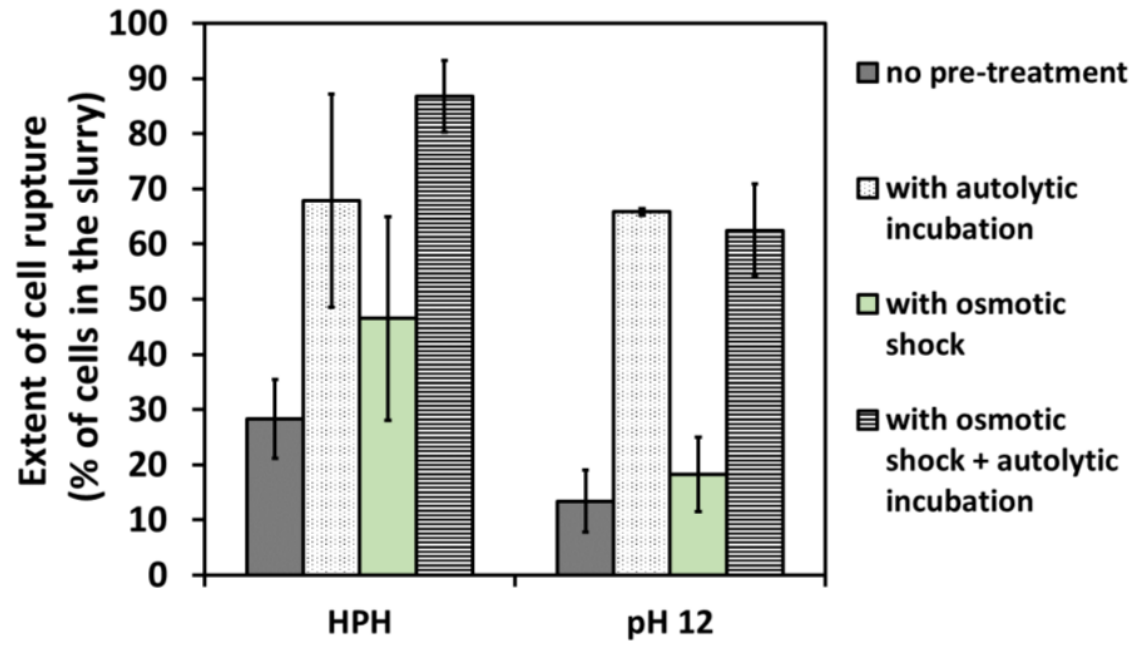

(a)

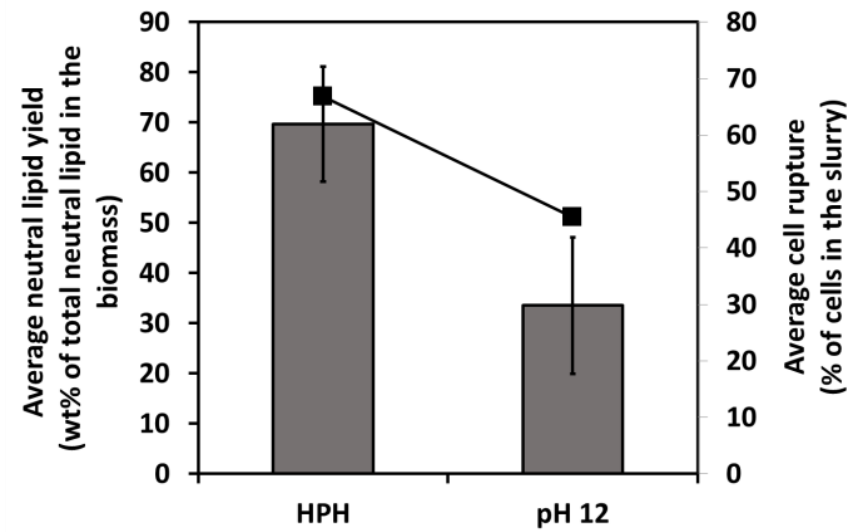

(b)

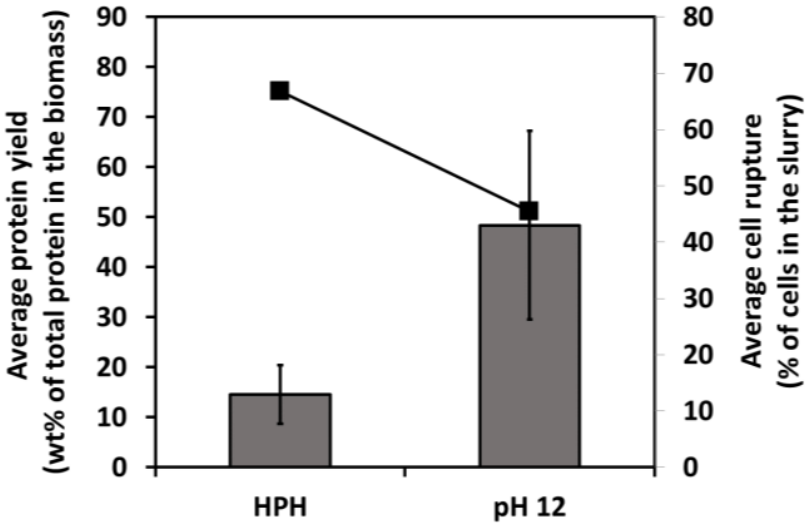

(c)

Figure 2: (a) The effect of pre-treatment on the disruption performance of mechanical disruption (HPH) and chemical disruption ( $\mathrm{pH}$ 12). (b) The effect of cell rupture on the neutral lipid yield obtained from mechanically disrupted (HPH) and chemically disrupted ( $\mathrm{pH} 12)$ biomass. The average values of cell rupture and neutral lipid yield were calculated across experiments involving HPH (experiment 5, 8, 11 in Table 1) or $\mathrm{pH} 12$ (experiment 6, 9, 12 in Table 1) (c) The effect of cell rupture on the protein yield obtained from mechanically disrupted (HPH) and chemically disrupted $(\mathrm{pH} 12)$ biomass. The average values of cell rupture and protein yield were calculated across experiments involving HPH (experiment $5,8,11$ in Table 1) or $\mathrm{pH} 12$ (experiment 6, 9, 12 in Table 1). 


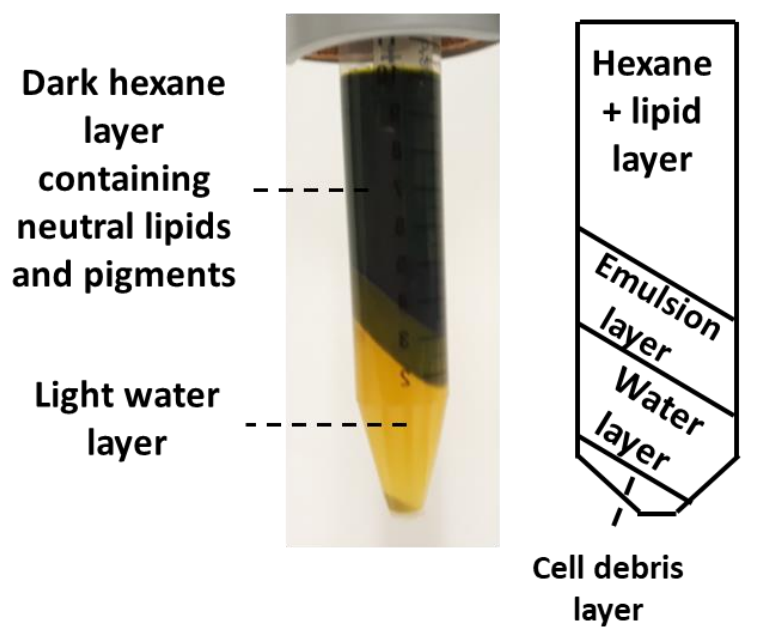

(a)

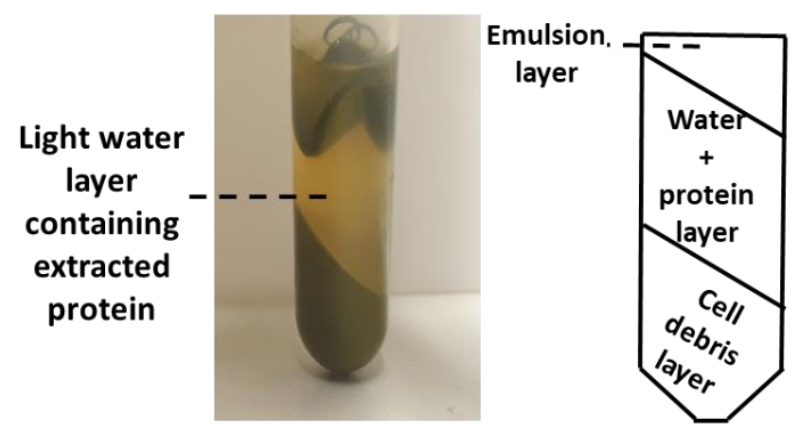

(c)

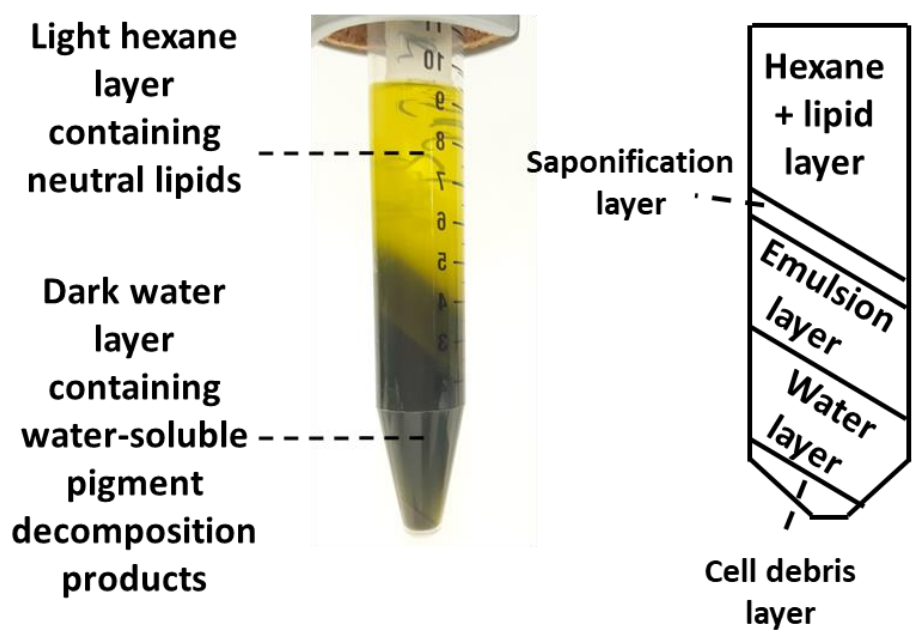

(b)

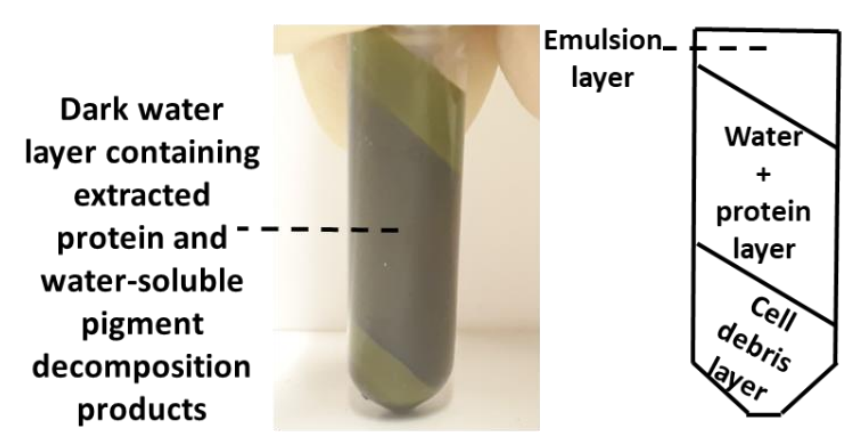

(d)

Figure 3. Representative layer partitioning of post-centrifuged neutral-lipid and protein extraction slurries (a) Neutral-lipid extraction layers for HPH (experiment 11), (b) Neutral lipid extraction layers for $\mathrm{pH} 12$ (experiment 12), (c) Protein extraction layers for HPH (experiment 11), (d) Protein extraction layers for $\mathrm{pH} 12$ (experiment 12). 


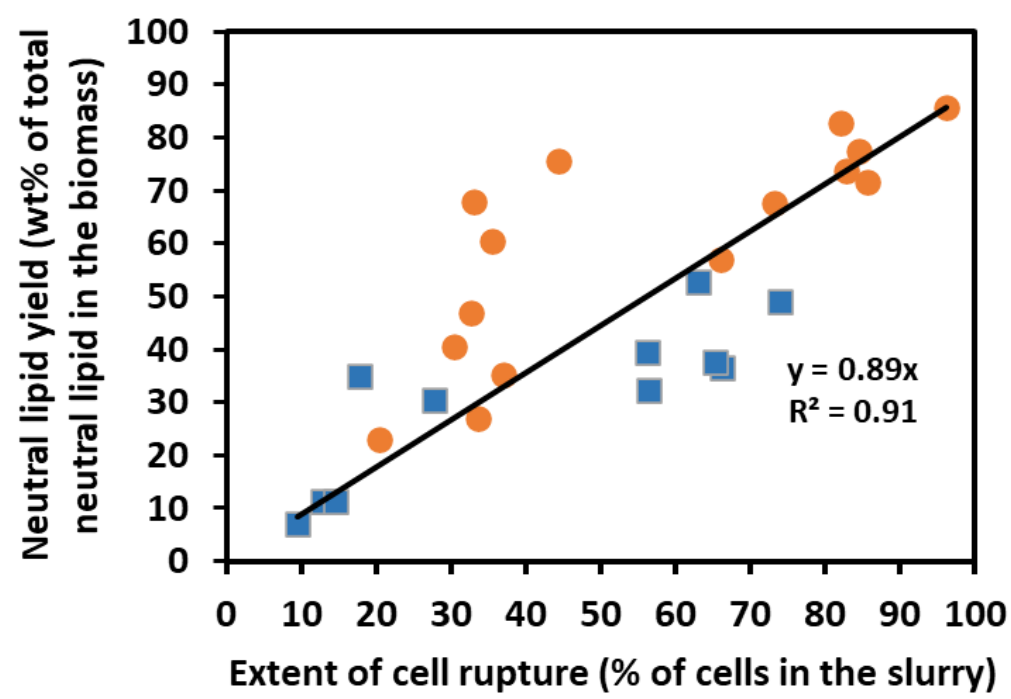

(a)

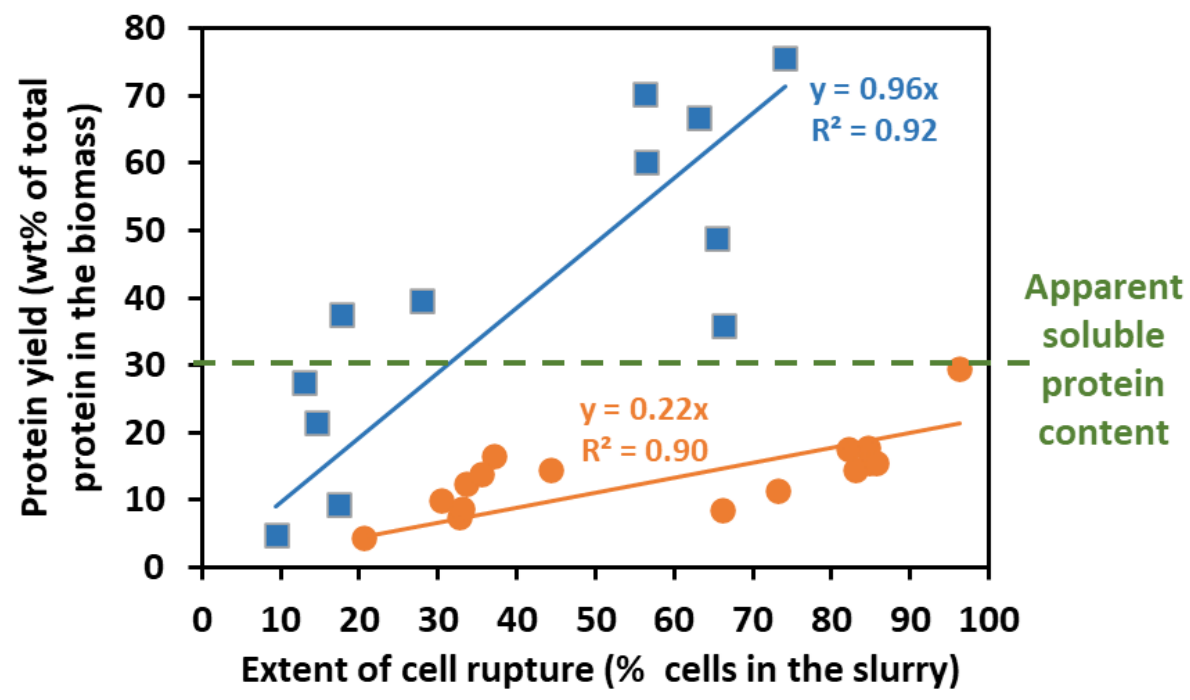

(b)

Figure 4. (a) Correlation between neutral lipid yield and extent of cell rupture. (b) Correlation between protein yield and extent of cell rupture. - mechanically disrupted biomass (HPH), $\square$ chemically disrupted biomass ( $\mathrm{pH}$ 12). Results from all experimental replicates in Table 1 (exp 2,5,8, 11 for HPH; $\exp 3,6,9,12$ for $\mathrm{pH} 12$ ) were collated to produce the correlations. 


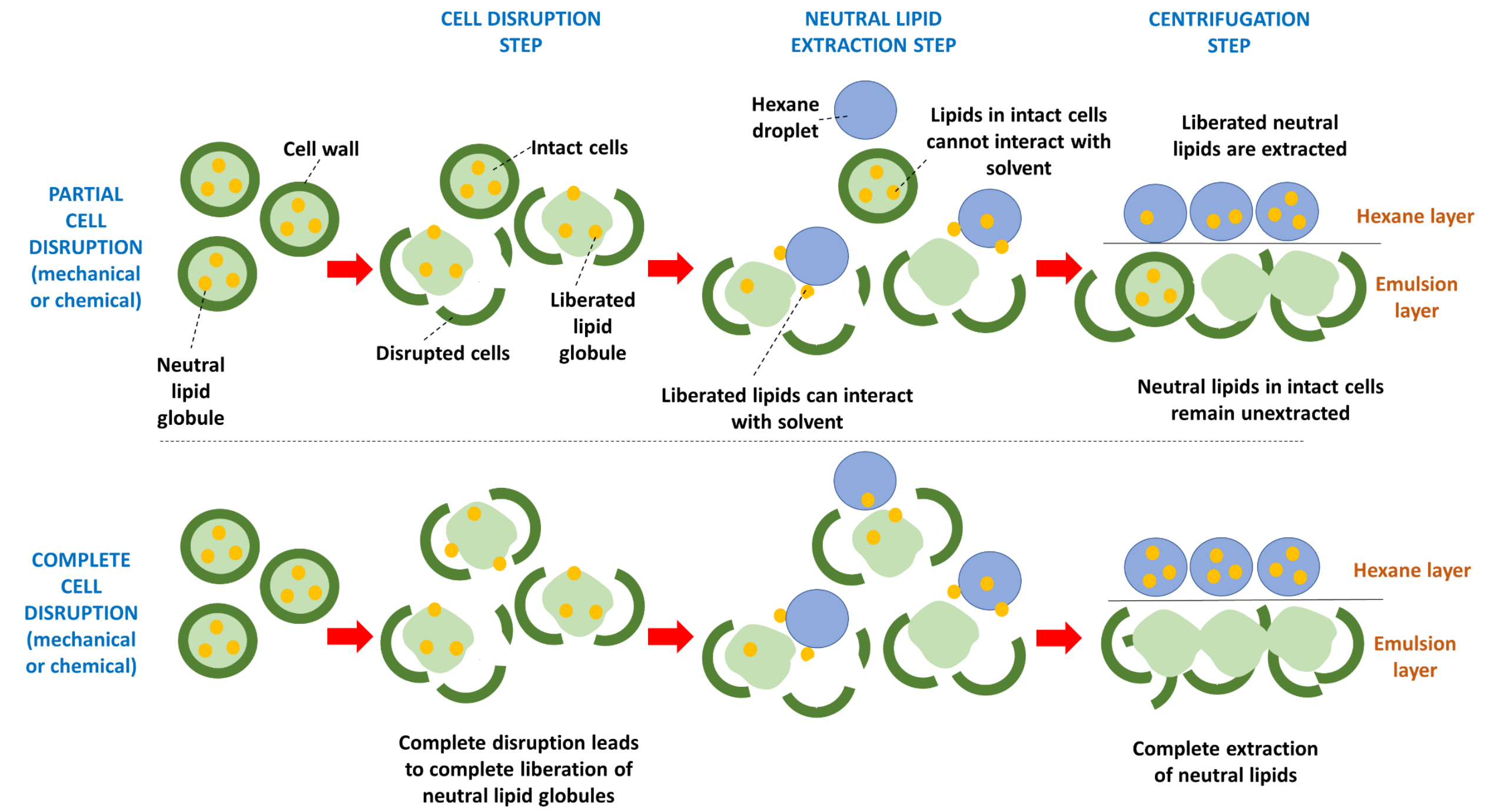

Figure 5. Proposed mechanism of neutral lipid extraction illustrating the direct dependence of neutral lipid yield on the extent of cell rupture 


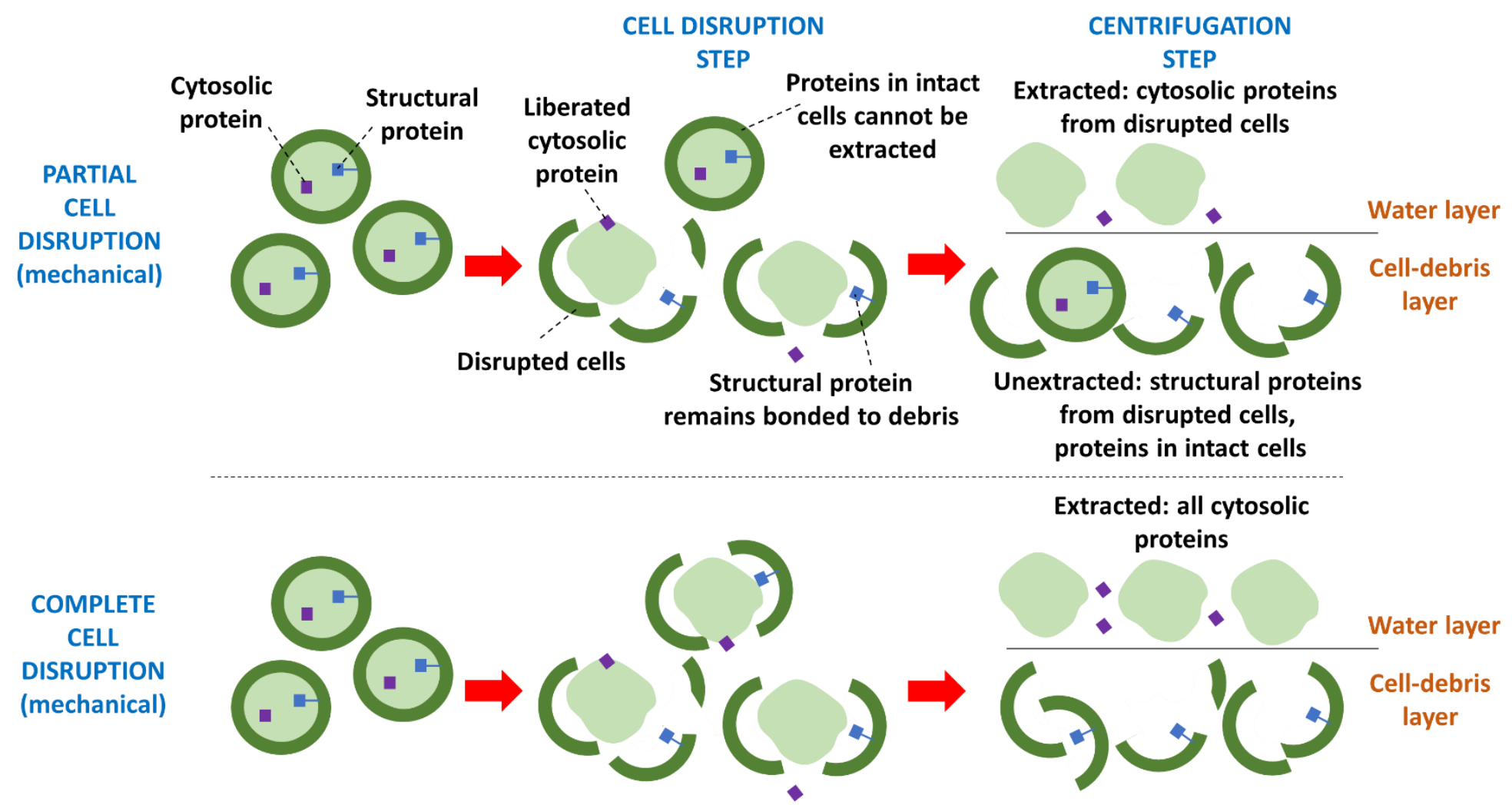

Complete disruption leads to complete liberation of cytosolic proteins

Unextracted: all structural proteins

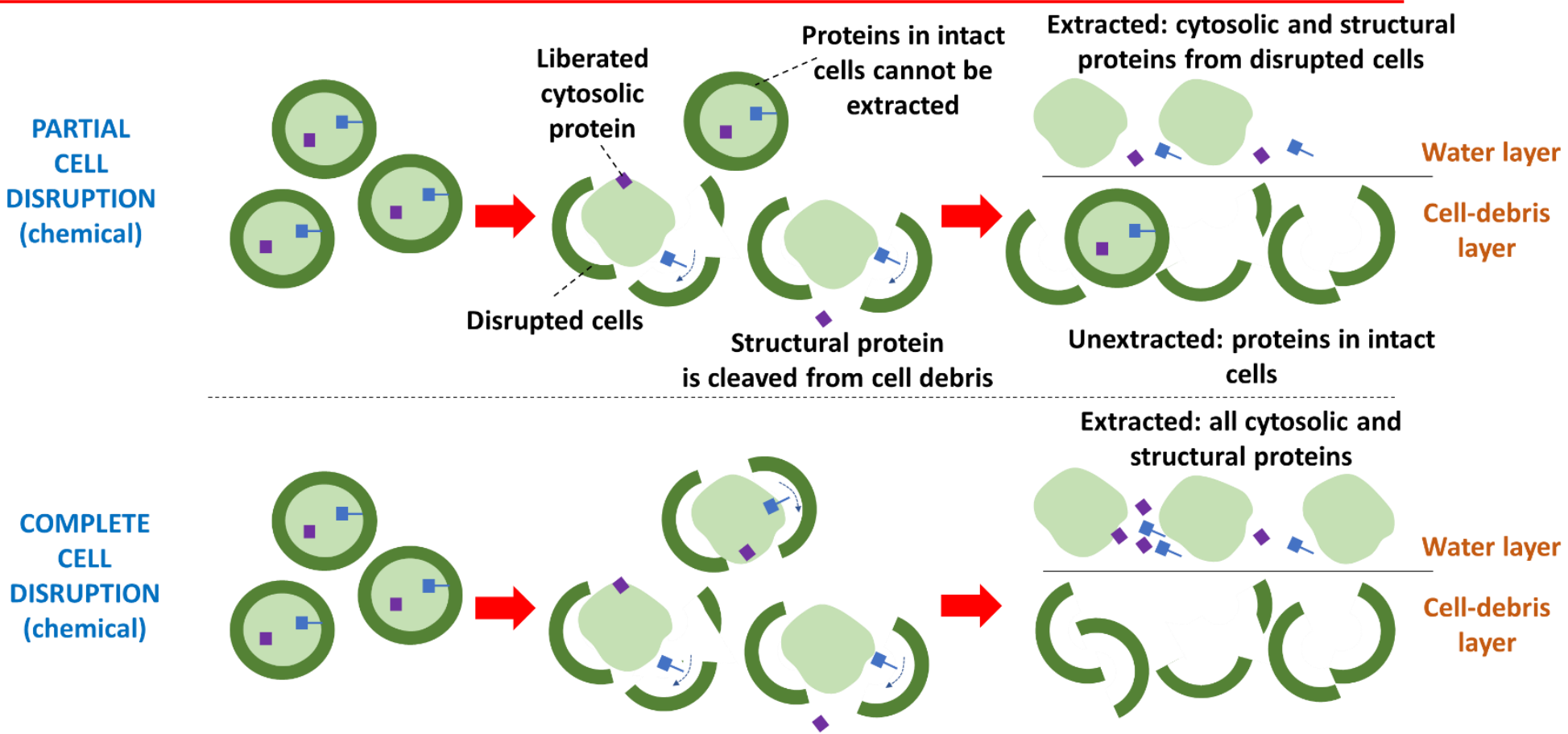

Complete disruption leads to complete

liberation of cytosolic and structural proteins

Figure 6. Proposed mechanism of protein extraction illustrating the complex dependence of protein recovery on both the extent of cell rupture and the hydrolysis of protein linkages. 


\begin{tabular}{|c|c|c|c|c|c|c|c|c|}
\hline \multirow[t]{2}{*}{$\begin{array}{c}\text { Experiment } \\
\text { no. }\end{array}$} & \multirow[t]{2}{*}{ Pre-treatment step } & \multirow[t]{2}{*}{ Cell disruption step } & \multicolumn{2}{|c|}{$\begin{array}{c}\text { Extent of cell rupture } \\
\text { (\% of cells in the } \\
\text { harvested slurry) } \\
\end{array}$} & \multicolumn{2}{|c|}{$\begin{array}{l}\text { Neutral lipid yield } \\
\text { (wt\% of total neutral } \\
\text { lipid in the biomass) } \\
\end{array}$} & \multicolumn{2}{|c|}{$\begin{array}{c}\text { Protein yield } \\
\text { (wt \% of total protein } \\
\text { in the biomass) } \\
\end{array}$} \\
\hline & & & mean & \pm std & mean & \pm std & mean & \pm std \\
\hline 1 & no pre-treatment & no disruption & 0.0 & 0.0 & 7.9 & 8.5 & 1.5 & 2.0 \\
\hline 2 & no pre-treatment & mechanical disruption (HPH) & 28.3 & 7.1 & 31.0 & 8.2 & 12.2 & 3.9 \\
\hline 3 & no pre-treatment & chemical disruption ( $\mathrm{pH} 12)$ & 13.4 & 5.6 & 4.0 & 5.7 & 6.7 & 2.4 \\
\hline 4 & autolytic incubation & no disruption & 10.3 & 8.4 & 5.1 & 1.2 & 9.8 & 3.1 \\
\hline 5 & autolytic incubation & mechanical disruption (HPH) & 67.8 & 19.3 & 65.7 & 12.2 & 13.0 & 4.8 \\
\hline 6 & autolytic incubation & chemical disruption ( $\mathrm{pH} 12)$ & 65.8 & 0.7 & 30.2 & 16.7 & 38.8 & 9.1 \\
\hline 7 & osmotic shock & no disruption & 15.4 & 8.5 & 23.0 & 13.5 & 10.1 & 4.1 \\
\hline 8 & osmotic shock & mechanical disruption (HPH) & 46.5 & 18.4 & 65.1 & 9.7 & 12.3 & 3.8 \\
\hline 9 & osmotic shock & chemical disruption (pH 12) & 18.3 & 6.7 & 19.6 & 11.5 & 30.7 & 9.9 \\
\hline 10 & osmotic shock + autolytic incubation & no disruption & 32.4 & 13.9 & 25.9 & 19.7 & 23.4 & 10.2 \\
\hline 11 & osmotic shock + autolytic incubation & mechanical disruption (HPH) & 86.8 & 6.5 & 77.8 & 6.6 & 17.4 & 5.7 \\
\hline 12 & osmotic shock + autolytic incubation & chemical disruption ( $\mathrm{pH}$ 12) & 62.5 & 8.3 & 41.1 & 10.7 & 66.2 & 8.6 \\
\hline
\end{tabular}

Table 1. Experimental matrix showing the different combinations of pre-treatment and cell disruption steps. The extent of cell rupture, neutral lipid yield and protein yield of each experiment are provided. 


\begin{tabular}{cc}
\hline Fatty acids & $\begin{array}{c}\text { Harvested slurry } \\
\text { (wt\% of total fatty acids } \\
\text { in the biomass) }\end{array}$ \\
\hline C14:0 & 2.7 \\
C16:0 & 42.0 \\
C16:1 & 35.2 \\
C18:0 & 1.5 \\
C18:1 (cis and trans) & 10.2 \\
C20:3 ( $\omega-6)$ & 2.7 \\
C20:5 $(\omega-3)$ & 5.6 \\
\hline
\end{tabular}

Table 2. fatty acid composition of biomass total lipid. 
